\title{
MIR574 Gene
}

National Cancer Institute

\section{Source}

National Cancer Institute. MIR574 Gene. NCI Thesaurus. Code C127130.

This gene may play a role in the modulation of target gene expression. 